\title{
Policy-Making of Strategic Plan in Success of Five Year Development Agenda of Pandeglang Regency of Banten Province
}

\author{
Andriansyah $^{1}$ \\ $\frac{\left\{\text { andriansyah@dsn.moestopo.ac.id }{ }^{1}\right\}}{\text { Universitas Prof Dr Moestopo }^{1}}$
}

\begin{abstract}
The policy-making of the five-year strategic plan of its substance involves participation in the process of policy formulation through Development Deliberation (Musyawarah) in the decentralization of regional autonomy. That is, it delivers the authority of the central government to the autonomous regions in determining the policy (political authority) and implementing the policy (administrative authority), based on local voice and local choice. The local government is expected to identify needs, formulate development goals, and make appropriate strategic plans (Renstra) to achieve its objectives. The research used qualitative method with descriptive approach by collecting various data from various sources with triangulation technique. The purpose of the study describes the three things, namely setting agenda, policy formulation and budgeting in a formulation of stakeholders' participation. Research results: First: participation in development planning in tokenism and elitist-party stages, partnerships between communities with bureaucracy and political officials are still subordinate union of partnership. Dialogue held is still pseudo and decision making is not done by bargaining among actors. Second: The quality of planning is still bad, because it has not been able to answer the needs of the community and there is no interconnected substance between documents with one another.
\end{abstract}

Keywords: policy making, strategic plan, decentralization

\section{Introduction}

The implementation of the research is done from the start of the formulation process to the stabilization of Policy and Implementation of Strategic Strategic Plan (Renstra). According to Abdullah [1], is to provide an overview and documentation review from the start of the process of policy formulation as reinforced by Yamit [2], in preparing five yearly planning for the Regional Device Work Unit (SKPD). As stated in the Regional Regulation (Perda) of Pandeglang Regency Number 6 Year 2008, regarding Formation, Organizational Structure and Work Procedure of Regional Devices of Pandeglang Regency.

This regulation is used as a reference for the drafting of the Work Plan (Renja) and Development Policy Development of Pandeglang Regency as stated in the Pandeglang District Medium Term Development Plan (RPJMD) as the implementation of regional autonomy Munir [3], and according to Law No. 25 of 2004, on the National Development Planning System and Law Number 32 of 2004, on Regional Government (Pemda). In this case the Regional Government of Pandeglang Regency as the object of research writing scientific articles. There are three substances that are submitted in article writing that is, first; writing is a scientific study of all documentation of the formulation and policy making of the development of Pandeglang Regency as outlined in the five-year Renstra at the Regional Government of Pandeglang Regency (Perda No. 1/2008, on Pandeglang District Government 
Affairs). Secondly, as a scientific study of operational technical planning and a technical translation of the RPJMD, including regional financial arrangements as the implementation of derivative programs of the RPJMD, (Permendagri No. 13/2006, Guidelines for the Administration of Regional Finance).

The author also outlines the Vision, Mission, Direction of Technical Policy and Indication of Program Plan of each Field of Authority and or Function of Pandeglang District Government (Permendagri No: 13/2006). Second; writing refers to the main duties and functions (Tupoksi) implementation of local government as a constitution that makes the process of formulating policies and public services, in addition to various policies and priorities Pandeglang local government program [4].

The development planning process from the lowest level requires active participation of all stakeholders in the area Muluk, [5]. Currently, the participation of stakeholders, including the community is still often ignored. To implement this system requires fundamental changes in attitudes of actors in regional development planning [6]. This system requires a change of public attitudes from passive to active, the parliament from criticizing to creating and bureaucracy from mastering to facilitating. Description of how the process of preparing an annual development plan that starts from the lowest administrative structure of the Kelurahan, continued at the sub-district level and eventually to the district level is necessary.

This is important, because in every level of government this is a good aspiration from the community, other stake holders bureaucracy submitted is expected to be realized [7]. The problems that often arise in the Strategic Plan development process are quality issues. The planning process will produce a quality plan. A quality plan tends to accommodate the interests of the various parties concerned with the implementation of a plan. The Analysis of the Formulation of Policy Implementation of Renstra in the implementation of development in Pandeglang Regency to date has not shown good coordination among the Local Government Work Units (SKPD), which impact on the implementation of development that is not touching the interests or needs of the community, especially in the field of people's welfare, labor), further described Ostrom [8], on variables involving public policy variables.

In the description above, it often shows in the development planning process according to Tjokroamidjojo [9], mentions that there is still empirically high percentage of school-aged children who do not get primary education, poor people not covered by the Public Health Insurance (Jamkesmas) unabsorbed workforce in employment.

According to Islamy [6], states that quality is a dynamic condition associated with products, services, people, processes and environments that meet or exceed expectationsto improve the effectiveness and efficiency of regional planning and budgeting, it is necessary to improve the planning and budgeting process, among others related to the flow of planning and budgeting process and the preparation of planning and budgeting documents should be consistent. In this regard, the quality of the process can be assessed from the planning and budgeting flow consisting of stages (1). Setting agenda setting, (2). Preparation of policy formulation and (3). Budgeting, and the linkage between planning and budgeting documents. In relation to the quality of development planning, the authors argue that quality development planning is a plan that can meet the needs and desires of stakeholders and consistent from the agenda setting, policy formulation and budgeting. Based on the background of the problems described above and related to the development planning process, the following issues are identified: (a) The mechanism of the planning process despite the applicable rules, but the stakeholders involved have not represented the community; (b) Weak enforcement of regulations in the development planning process, in the absence of sanctions for violating provisions in the development planning process; (c) The existence of interventions of interest groups in the development planning process, making it difficult to apply priority scale in financing the activities that have been proposed.

Starting from the various problems identified above and looking at the problem above, the analysis of the formulation and implementation of the Policy of the Strategic Plan which constitutes the embodiment of the National Program (Propenas) and the Development Work 
Plan contained in the five-year Regional Development Work Plan RPJMD) 2015-2016. From the explanation and referring to the identification of existing problems, the question of the Problem Formulation of the authors are: (a) How is the participation of the community and stakeholders in the Pandeglang District Government Strategic Plan 2015 - 2016? (b) What is the quality of RanstraPandeglang 2015 - 2016? The purpose of writing is: to conduct a documentation review on the analysis of the formulation of policy implementation Strategic Plan (Renstra) Local Government of Pandeglang Regency Year 2015-2016. So it is expected to be an input for readers and policymakers in making Renstra in other Kota Districts. General Purpose of writing: (a) To describe the participation of stakeholders in development planning in Pandeglang Regency in 2011-2016; (b) To describe the quality of development planning in Pandeglang Regency for budget year 20015-2016. Specific objectives: (1) Proactively anticipate changes that occur within the scope of the Organization of Regional Devices (OPD), so that service can be done primarily through the intensity of communication with all Stakeholder; (2) Determine the performance benchmarks of a program to conduct annual performance evaluation of the Pandeglang District Secretariat; (3) reading reference materials for other LGs that will make the Plan Stratefis policy placement in the district and district secretariats. The research methodology used qualitative method approach, with approach of description of phenomenon or social reality.

Descriptive research is intended for exploration and clarification of a phenomenon or social reality, by way of describing a number of variables related to the problem and the unit under study. As explained above, in the regional annual development planning process involving various stakeholders, this will be able to know how much participation and how the quality of the resulting plan [7].

\section{Result and Discussion}

2.1 Concept of Regional Development (Territory)

Katz argues that development as a planned process of change from one national situation to another national situation is higher in Tjokrowinoto [9]. The essence of development is a steady and steady progress towards improving human living conditions whereas development is a process of improving the standard of living of society as a whole dynamic.

Henry Maddick[10], decentralization includes the process of deconcentration and devolution. Deconcentration is the delegation of sufficient authority to release special functions to staff from a central department outside the head office. Devolution is the legitimate granting of power to dispose of specified functions or residual functions on locallyenforced formal authorities.

\subsection{Concept of Planning Policy Discussion}

The formulation of objectives and the design of alternative actions (programs / activities) became the most dominant thing in the planning. The purpose of regional development planning is in order to answer the needs of the community to achieve certain goals. According to Munir [3] based on the timeframe, planning can be divided into: (a) Long-term planning, usually has a time span of 10 to 25 years. Long-term planning is a development blueprint that must be implemented over a long period of time; (b) Medium-term planning, usually having a time span of 4 to 6 years. In medium-term planning though still common, but goals in large groups (sectoral targets) can already be clearly projected; (c) Short-term planning, has a time span of 1 year, usually called annual operational plan. When compared to long-term and medium-term plans, short-term plans are usually more accurate [6].

From the above definitions, conclusions can be drawn about the annual regional development planning can be defined as the process of preparation of plans that have a period of one year which is the operational plan of the long-and medium-term plan that contains the steps of setting goals and policy / program / activity selection to address the needs of local 
communities as well as the control of implementation of the implementation program on public sector analysis [8]

\subsection{Plot of Regional Development Planning}

In the author's opinion, for the seventh to the ninth step is not part of the planning, but is part of the execution process. The explanation of the first step up to sixth is: (a) Determination of goals The goal is an expression of a value associated with an ideal future condition to be achieved. Source of destination is usually from the Constitution or the Law which has been established previously; (b) Assessment of needs Requirement is the demand for a better state. Needs assessment is a determination of the size of the conditions occurring in society, where decision makers are expected to improve or fulfill them; (c) Specification of objectives In this step is to set targets or outcomes to be achieved / measurable which is an operational definition of a predetermined objective; (d) Design of alternative actions This step is to identify or design some alternative actions to be taken by decision-makers to achieve a predetermined goal.

Planning is closely related to policy making. In fact both are often interchangeable. According to Mayer the difference is more due to the historical development of the literature and not in the sense attached to the term. Anderson [11], says that the policy is "A purposive course of action followed by an actor or set of actors in dealing with a problem or matter of concern. (B) preparation of the agenda (agenda setting), (c) formulation of proposals, (d) approval of policies, (e) implementation of policies, and (f) policy assessment. In the author's opinion, the fifth and sixth steps are not included in the policy formulation process but are included in the policy cycle.

\subsection{Overview of Local Government Service of PandeglangRegency}

This writing is expected to illustrate the implementation of government tasks in carrying out the development to support the implementation of regional autonomy which is highly dependent on the ability of its apparatus. Therefore, in achieving the expected goal required employees who have the competence and discipline with the accompanied also the increase and development of institutional and apparatus resources.

Competence is concerned with the level of skills and knowledge, improving the quality and capacity of apparatus resources within the Regional Secretariat of Pandeglang District is very important to be done, since in the era of regional autonomy now demands professionalism of employees in understanding strategic issues to be able to formulate a synergistic policy, with the increasing of Community Resources which will of course have an impact on the demands of improving the quality of public services and it also depends also on the existing facilities and infrastructure at the Regional Secretariat of Pandeglang Regency.

\section{Conclusion}

Participation, in the development planning policy process in Pandeglang Regency for the fiscal year 2015-2016 is still tokenism that is still merely a symbolic act and is still elitistrepresentative. The partnership between the community and the bureaucracy and the political officials as well as between the bureaucratic sub-districts and the urban bureaucracy is still a subordinate union of partnership. Bureaucracy and political officials have access and have wide authority in every stage of planning compared to other actors. Dialogue is still less effective, because the exchange of information between bureaucracy and political officials with the community has not been established. The quality of Regional Development Planning in Pandeglang Regency is still poor, because it has not been able to answer the needs of the community, has not had a clear plot of planning, and there is no interconnected substance between planning documents with each other. Planning mechanisms still rely on hierarchical activity proposals from physically oriented bureaucracies and have not yet comprehensively addressed the emerging strategic issues in society. 


\section{References}

[1] A. I. Abdullah, Dictionary of Accounting. Jakarta: Mario Grafika, 1995.

[2] J. Yamit, Quality Management of Products and Services. Yogyakarta: Econosia, 2001.

[3] B. Munir, Regional Development Planning in the Perspective of Regional Autonomy, 2nd ed. Mataram: Bappeda NTB Province, 2002.

[4] I. Bastian, Public Sector Accounting in Indonesia. Yogyakarta: BPFE, 2001.

[5] K. M. R. Muluk, "Paper: Achieving Public Participation in Local Government," 2005.

[6] I. M. Islamy, Principles of State Policy Formulation. Jakarta: Bumi Aksara, 2003.

[7] S. Faisal, Social Research Formats. Jakarta: Raja Grafindo Persada, 2005.

[8] E. Ostrom, Formulating the elements of institutional analysis. Paper presented to a Conference on Institutional Analysis and Development. Washington DC, 1985.

[9] B. Tjokroamidjojo, Development Planning, 18th printing in 1985. Jakarta: Toko Gunung Agung, 1996.

[10] H. Maddick, Decentralization in Practice (translation). Yogyakarta: Pustaka Kendi, 1957.

[11] J. E. Anderson, D. W.Brady, and C. Bullock, "Public policy and politics in the United States," Massachussets, Duxbury, 1978. 